\title{
Social exclusion of the Roma population in Slovakia (selected characteristics of habitation)
}

\author{
JOZEF MLÁDEK, JANA PUKAČOVÁ \\ Comenius University in Bratislava, Faculty of Natural Sciences, \\ Department of Human Geography and Demogeography
}

\begin{abstract}
Primarily, the objective of this paper is to assess the basic infrastructure like the existence of water, electricity, and gas mains and the sewage in Roma settlements. A comparatively lower dwelling level has been observed above all in segregated Roma settlements. Five categories of Roma settlements have been classified by using of the point method. Comparison of infrastructure available to the majority in concerned municipalities is important and illustrative for the exclusion of the Roma population. Roma settlements seem to be marginalized and it is precisely where the exclusion is obvious not only in terms of the dwelling level but also in terms of working opportunities, education and health care.
\end{abstract}

Key words: social exclusion, Roma population, segregated settlements, technical infrastructure, categories of Roma settlements

\section{Social exclusion}

Social exclusion is the process when certain individuals or population groups are displaced to margins of the society. The cause of such position is the precluded participation on economic, social and cultural life of the society. Most often it is the case of limited opportunities of lifelong education, barriers to participation on labour market and decision-making bodies/authorities.

In assessment of social exclusion the principal theme is the incapacity of a given society to fully include certain individuals or population groups (religious, ethnic, spatial, gender or other) in the social system, which would offer them the full realization of their potential. Džambazovič (2004) points to the assertion of Berghman according to whom social exclusion is the consequence of society's failure not that of an individual. Social exclusion is caused by social conditions, economic arrangements of the society, unjust distribution of sources, bad legislation, discrimination and the like. Sedová (2007) emphasizes an unequal access of inhabitants to five social sources: employment, health care, education, dwelling and social protection. 
Exclusion is also interpreted as incapacity to efficiently participate in economic, political, and cultural life of the society. In economic sphere, this manifests itself in a low income, which hinders from equal social participation. In the political sphere, it is absence of a full-value citizenship (rights and duties). In the cultural sphere, it is a lower educational level or qualifications of population (Mareš 2004).

Social exclusion is sometimes compared with poverty. The category of poverty (material privation) is mostly based on assessment of living conditions and indicates the condition when the basic conditions for a dignified life are not secured and elementary human needs are not satisfied (shortage of food, drinking water, clothing, dwelling, health care, etc.). The concept of social exclusion though was given a substantially wider and more comprehensive view (Džambazovič 2002, 2004, Mareš 2004). Its multidimensional nature is emphasized. Social processes that cause poverty are recognized. Sometimes the dynamic analysis of processes leading to social processes is stressed against the static nature of the poverty assessment. Social exclusion is then interpreted as a systemic process of marginalization, isolation and weakening of social linkages. It is often identified with social isolation.

Application of the spatial aspect to social exclusion is highly important for the geographical approach to the issue. Many manifestations of exclusion are characterized by spatial concentration and are presented in distinct spatial forms (groups). Sedová (2007) denoted this aspect of exclusion a manifestation of social diversification and spatial polarization of society.

Primarily, the objective of this paper is to assess the basic infrastructure like the existence of water, electricity, and gas mains and the sewage in Roma settlements. A comparatively lower dwelling level has been observed above all in segregated Roma settlements. Information about spatial differentiation of the dwelling quality of the Roma ethnicity in Slovakia also represents a considerable contribution to the overall knowledge of the theme.

\section{Social exclusion of the Roma population}

Social exclusion of the Roma population in Slovakia is a serious problem that has formed in a long-year historic process since the arrival of the Roma people at Europe and Slovakia. Positive and negative attitudes of the majority alternated in this historic process, coexistence or social integration. The fact that science, educational and decision-making bodies devote great attention to social exclusion now, it means that the efforts of the two concerned parties were not successful so far. On the contrary, the mechanisms and forms of social exclusion have intensified in particular in case of population living in the Roma settlements because it is where the exclusion manifests in extremely negative forms.

The process of social exclusion of the Roma people in Slovakia is subject to various mechanisms and forms (Džambazovič, Jurásková 2002, Mareš 2002, 2004, Džambazovič 2004, Radičová 2002).

Economic exclusion is based on an unfavourable position on labour market and eventually unemployment. Especially the inhabitants of segregated settlements find it 
difficult to enter the labour market so their unemployment rate is extreme. Numerous groups of the Roma population depend on social assistance of the State. The result is the shortage of economic resources that projects into the low living standard, low dwelling standard, etc.

Cultural exclusion is the result of insufficient participation of individuals or population groups in culture of society while the access to education is decisive. Low educational levels (part of young Roma do not even have the elementary education) are also the cause of exclusion in other spheres of life above all the labour market.

Symbolic and psychological exclusion is connected with perception of marginal groups by the society through prejudice, refusal and negative stereotypes. Discrimination of the Roma people on labour market is often associated with stereotypes about unreliable labour lacking motivation, which in turn is connected with the low level of education and absence of qualifications. The long-term development of negative phenomena creates a certain image about the way and living conditions in the margined groups. Such image is "hereditary" and it is handed on from one generation to another.

Political exclusion represents the limited participation in civic, political and basic human rights. Beside other, it manifests itself in an incapacity and disinterest in management or administration of proper communities, in a low level of organization and management of proper political interests.

Exclusion from access to social services represents certain limitations in use of health service and various administrative services.

Spatial exclusion manifests itself in concentration of excluded individuals or groups into certain spatial units. Marginalization in Slovakia is conspicuous in form of segregated groupings (rural settlements and urban ghettos). Radičová (2002) points to the phenomenon of a double marginalization. Many of the segregated marginalized settlements are in regions subject to low economic and social development (high unemployment, high social dependency rates, poverty indicators and the like). It complicates the position and social exclusion of the Roma ethnicity and solutions are more difficult.

The sense of classification of social exclusion into certain forms is above all gnozeological. Such forms occur in combination. Almost all of them overlap; they are interlinked and mutually dependent. The low educational level does not allow for equal participation on labour marked and causes social exclusion. Unsufficient finances do not allow for increasing of the dwelling standard and the necessary equipment. If the negative effects of such factors last for a long time, the image of social exclusion and impossibility to change the situation is created.

\section{Dwelling level of the Roma minority as a form of social exclusion}

The Roma people present in the territory of Slovakia since the $14^{\text {th }}$ century have always formed separated dwelling groupings, settlements. The concept of a Roma settlement though, has not been defined so that its perception varies. In the 1990s, the concept of "dwelling groupings on a low socio-cultural level" has been introduced in reference to such a settlement. As Eva Davidová reports: "The Roma (Gypsy) 
settlement is a group of houses where at least several Roma families live together normally in isolation from other population of the municipality" (Davidová 1995, p. 67). According to the Amnesty International, rural settlements and segregated parts of smaller towns and villages inhabited by the Roma communities can be considered the Roma settlements (Stále segregovaní, stále... 2007). A Roma settlement in the study of Jakoubek and Poduška is perceived as an enclave in a part of municipality inhabited by the Roma persons who are carriers of a specific culture (Jakoubek 2003). Individual Roma settlements are quite different just as the Roma proverb says: Šel vatri, šel Roma (Hundred Romas, hundred settlements) (Horváthová 2002).

No detailed and precisely defined characteristics of the Roma settlements existed in Slovakia before 2004, when results of the so-called sociographic mapping of the Roma communities were published. The principal objective of this sociographic mapping was to report and compile the picture how this minority lives in Slovakia.

The sociographic mapping of the Roma communities was carried out all over the Slovak territory in time from September 2003 to June 2004. The municipalities where the Roma population amounted to less than 15 were not included. But if the situation of Roma people in such municipalities was troublesome in terms of dwelling, living standard or the relationships with the majority it was included into the survey. The principal unit applied was the Roma community defined as the group of persons subjectively defined by the majority as Roma based on anthropological features, cultural appurtenance, way of life, life style, living space and also subjectively perceived as different both in positive and negative sense (Radičová 2004, s. 9).

\subsection{Roma settlements}

The grouping of Roma communities in the sociographic mapping is referred to as the settlement, which is defined as a minimum of three houses inhabited by population perceived as Roma. The concept of settlement will be replaced by that of the Roma settlement in further characteristics of the Roma communities in Slovakia according to the results of this mapping. Hence, the basic feature is not the type and character of dwellings, rate of integration, links to the majority or the very location of the settlement but inhabitants of such groupings referred to by the majority as Roma. It means that in his paper, any permanently residing grouping of Roma is considered the Roma settlement.

In the territory of Slovakia, 1,575 Roma settlements of different type were identified in 2004. Their total population was 261,959 concentrated in the east of the country where Roma live in 495 settlements equalling to more than $50 \%$ of all settlements in two administrative regions of Košice (430) and Prešov (365). In spite of the fact that the number of settlements is low in the regions of Prešov, the number of Roma is the highest (more than 80 thousand Roma persons equalling to almost 31\% of all Roma). The second most populous is the region of Košice (more than 78 thousand equalling to almost 30\% of all Roma). The third administrative region with the highest concentration of Roma is that of Banská Bystrica (392 settlements) inhabited by almost 53 thousand Roma (20\%). A substantial part of the Roma settlements (75.4\% of the national total) with 211 thousand inhabitants $(80.4 \%)$ live in the above-mentioned administrative regions. Accumulation of the Roma minority in the east of the country is related to the overall historic development 
of the settlement of this territory by the Roma people in spite of varied governmental regulations meant to dissipate or to displace the communities (Fig. 1 and 2).

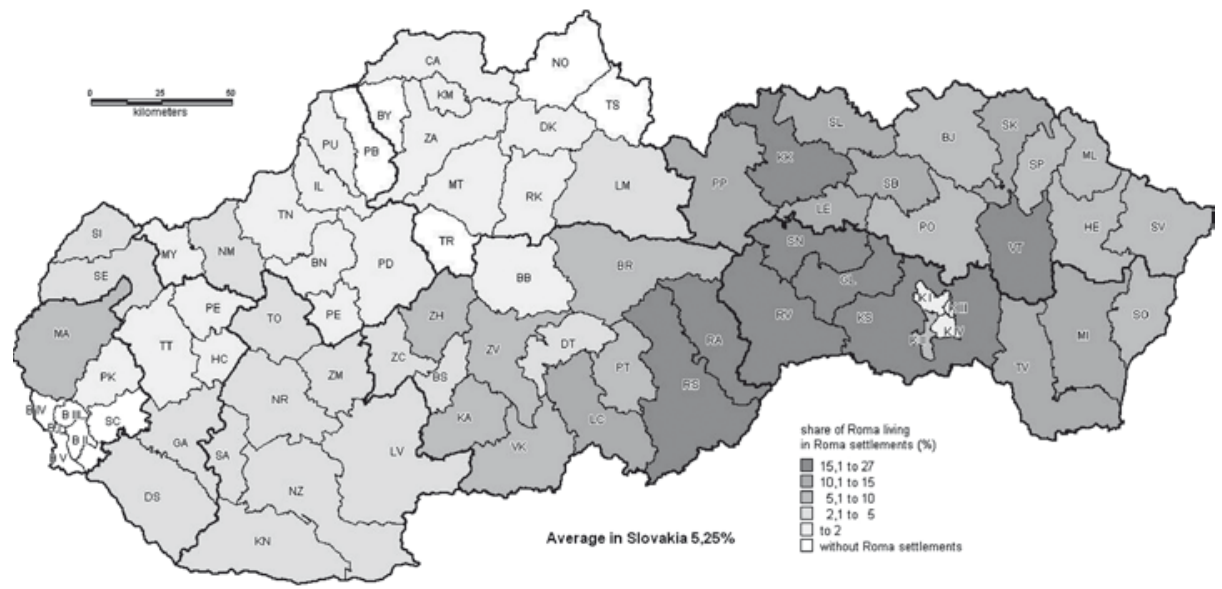

Fig. 1 Roma in Slovakia in the period 2003-2004

Source: Atlas rómskych komunít na Slovensku, 2004

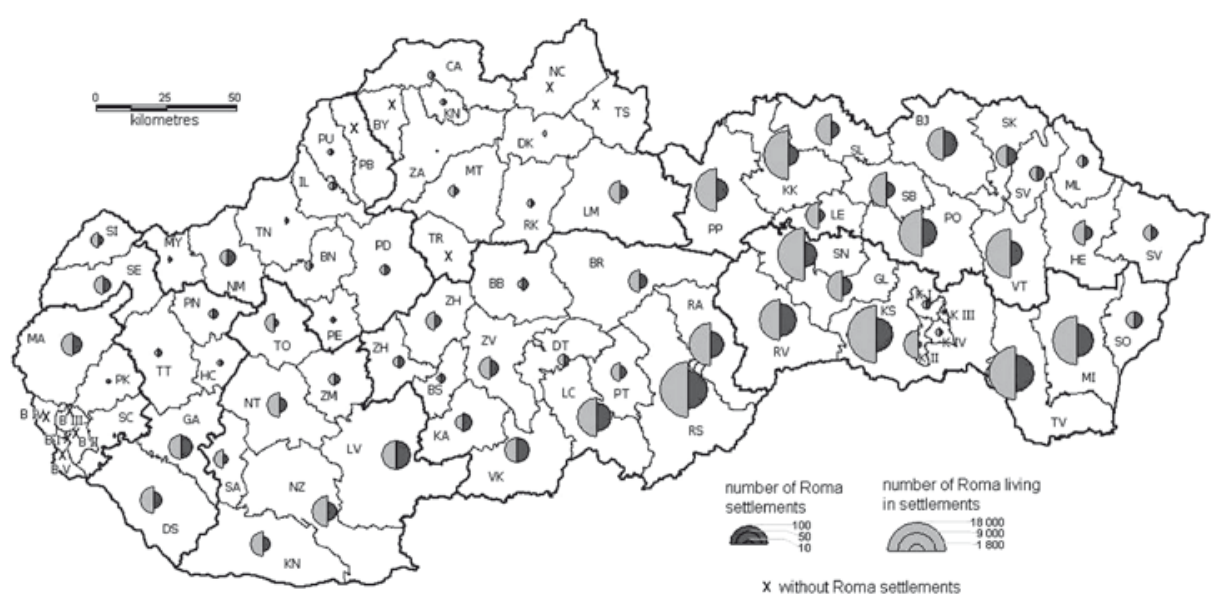

Fig. 2 Number of Roma living in Roma settlements in the period 2003-2004

The very location of Roma settlements is a factor of social exclusion of this minority. As far as the situation of the Roma settlements is concerned, they fall in four categories:

- Integrated/dispersed: Roma people live dispersed among the majority population within municipalities.

- Integrated/concentrated: Concentration of dwellings at any place within a municipality where more than $80 \%$ of Roma live.

- Settlements on the edge of a municipality: Roma live concentrated in a given place located on the edge of the built-up fabric of the municipality. 
- Settlements outside municipalities: Roma live in an area retired from the municipality; normally it is an urbanistic unit. In some cases, they are separated from the municipality by some kind of a boundary/barrier (for instance: a brook, wood, field, railway, premises of a cooperative, etc.).

The positive finding of the mapping was that almost $50 \%$ of Roma settlements are considered of the integrated/dispersed type, followed by $11 \%$ of concentrated settlements, $21 \%$ of settlements are located on the edge of municipality, and $18 \%$ (281) of settlements are situated outside municipalities. In a way they can be considered segregated forms. Segregation in general is interpreted as separation of a certain part of population because of different reasons (racial, religious, social or ethnic). Precisely these settlements are assessed as spatially excluded and a high rate of poverty is typical for them. In reality it means that the unemployment level is almost $100 \%$; health condition of the population is worse than in other areas; educational level is low (Chudoba Rómov... 2002, Džambazovič, Jurásková 2002). These settlements are often comparatively retired from the municipalities, several kilometres of distance is no exception. The access roads to the settlement are mostly dirt roads.

Great part of segregated settlements is situated in the administrative regions of Košice (111 settlements) and of Prešov (83 settlements). Pursuing the mapping, in total 43,353 Roma live in such excluded settlements in the east of the country. The figure represents more than $87 \%$ of inhabitants of all segregated settlements (tab. 1). The region of Banská Bystrica boasts 63 segregated settlements (with population of 4,586). The number of segregated Roma settlements in the remaining administrative regions is much lower; in Trnava it is 10 settlements (397 persons), and in Bratislava and Žilina it is 5 settlements in each. While in Bratislava only 123 Roma live in such settlements, in administrative region of Žilina it is 886 persons; 250 Roma live in four segregated settlements in administrative region of Nitra. Regarding the segregated settlements, the best situation is in Trenčín where such type of the Roma settlements does not exist at all.

Table 1 Segregated Roma settlements in Slovakia in the period 2003-2004

\begin{tabular}{|l|c|c|c|c|c|}
\hline region & $\begin{array}{c}\text { number of } \\
\text { settlements }\end{array}$ & Population & $\begin{array}{c}\text { number of } \\
\text { dwellings }\end{array}$ & $\begin{array}{c}\text { proportion of } \\
\text { illegal dwellings } \\
\text { (\%) }\end{array}$ & $\begin{array}{c}\text { population } \\
\text { per } \\
\text { 1 dwelling }\end{array}$ \\
\hline Banskobystrický & 63 & 4586 & 900 & 26.0 & 5.1 \\
\hline Bratislavský & 5 & 123 & 28 & 35.7 & 4.4 \\
\hline Košický & 111 & 23621 & 3113 & 47.5 & 7.6 \\
\hline Nitriansky & 4 & 250 & 68 & 13.2 & 3.7 \\
\hline Prešovský & 83 & 19732 & 2652 & 66.3 & 7.4 \\
\hline Trnavský & 10 & 397 & 74 & 6.8 & 5.4 \\
\hline Žilinský & 5 & 886 & 128 & 65.6 & 6.9 \\
\hline Slovakia & 281 & 49595 & 6963 & 51.4 & 7.1 \\
\hline
\end{tabular}

Source: Atlas rómskych komunít na Slovensku, 2004 
These isolated settlements are almost always illegally constructed on a plot of other owner. Precisely this fact poses the greatest barrier to the improvement of life of the Roma groupings as it is not possible to build the technical infrastructure on someone else's land and to incorporate it into illegal structures. The buildings in such settlements do not meet the elementary technical standards, as they are mere huts. The 2004 mapping identified in total 6,963 dwellings including only 3,384 legal ones in the Roma communities living in Slovakia. The legal dwellings are entered in the cadastre of estates. More than $50 \%$ of the Roma dwellings are illegal and their inhabitants built them by their own bootstraps without any permission, so the dwelling can be pulled down anytime without compensation. The greatest number of illegal dwellings in segregated Roma settlements is in the administrative region of Prešov (1,757 dwellings, i.e. $66,3 \%$ of all dwellings are illegal). In administrative region of Košice with the highest number of dwellings $(3,113)$, almost $48 \%$ are illegal.

Overpopulation, namely that of individual dwellings, is the great problem of segregated dwellings accompanied with absence of an intimate space (own bed, writing desk, a playroom) for each family member. Big families dwell in a single room (the dwelling consists of a single room, a phenomenon not rare in segregated settlements) where all day and night activities are pursued (sleep, cooking, preparation of school duties). The Slovak average is 7.1 residents per a dwelling in a segregated settlement while in the region of Košice it is 7.4 residents per dwelling. However, it is quite normal that much more persons inhabit a dwelling. For instance, 19 persons live in a single dwelling in the settlement next to the village of Nižná Jablonka, or 16 Roma throng in one dwelling at Šarišské Čierne or at Somotor.

\subsection{Technical equipment of segregated Roma settlements and dwellings}

Technical equipment of a dwelling plays an important role in terms of the living standard assessment. Limited or no access to the primary communal networks is typical for segregated Roma settlements. Presence of technical infrastructure was surveyed not only within the Roma ethnicity but also in the majority population. The first observed characteristics was the access to infrastructure which showed whether inhabitants of the Roma settlements and the majority in the municipality adjacent to such settlements have access to the electricity, water, gas mains and the sewage, hence the possibility to use them.

The definitely best accessible for the majority and the Roma settlements is the electrical network. The majority population enjoys an almost $100 \%$ coverage by electricity while for the segregated Roma settlements it is almost $\mathbf{8 6 \%}$. Completely inaccessible is electricity for the Roma people in 25 settlements mostly in administrative regions of Košice and Banská Bystrica.

In case of the water main, $79 \%$ of majority municipalities have the option to use it compared to only $47 \%$ Roma settlements. The worst conditions were found in administrative regions of Košice and Prešov where there are 55\% of settlements with no access to the water main.

The most conspicuous inequalities in infrastructure accessibility that ensue from the comparison between the majority and the Roma ethnicity are in gas supply. Gas is 
supplied to $64 \%$ of majority municipalities compared to only $\mathbf{1 2 . 1 5 \%}$ of Roma settlements that enjoy access to gas.

Sewage network is the one with the worst accessibility not only in connection with the Roma settlements where $\mathbf{9 5 \%}$ of them lack a soil branch but also in case of the majority population living in adjacent municipalities where $88 \%$ of them lack a soil branch though they do use cesspools.

The mapping also identified the number of the Roma dwellings with access to infrastructure i.e. the rate of usability of accessible infrastructure by the Roma minority in individual settlements. Electrical network is the one most frequently used by the Roma. Almost $\mathbf{8 0 \%}$ of all segregated Roma dwellings have the electricity installed although with illegal offtake (tab. 2).

Situation in use of water main is worse. Only about $\mathbf{2 1 \%}$ of dwellings have access to the water main. Comparatively critical situation was found in the administrative region of Košice where only $10 \%$ of dwellings use the water main.

Table 2 Basic characteristics of segregated Roma settlements in Slovakia in the period 2003-2004

\begin{tabular}{|l|c|c|c|c|c|c|}
\hline \multirow{2}{*}{ region } & \multicolumn{2}{|c|}{ proportion of dwellings connected to the } & \multicolumn{2}{c|}{$\begin{array}{c}\text { settlements without } \\
\text { infrastructure }\end{array}$} \\
\cline { 2 - 8 } & $\begin{array}{r}\text { water } \\
\text { supply }\end{array}$ & $\begin{array}{c}\text { sewerage } \\
\text { gas mains }\end{array}$ & electricity & $\begin{array}{c}\text { number of } \\
\text { settlements }\end{array}$ & population \\
\hline Banskobystrický & 50.1 & 32.2 & 0.6 & 82.1 & 10 & 284 \\
\hline Bratislavský & 53.6 & 14.3 & 0.0 & 67.9 & 1 & 18 \\
\hline Košický & 9.5 & 9.3 & 3.9 & 68.9 & 8 & 729 \\
\hline Nitriansky & 11.8 & 0.0 & 0.0 & 36.8 & 0 & 0 \\
\hline Prešovský & 22.7 & 0.9 & 1.5 & 91.3 & 3 & 229 \\
\hline Trnavský & 58.1 & 10.8 & 23.0 & 83.8 & 2 & 50 \\
\hline Žilinský & 53.1 & 37.5 & 3.9 & 94.5 & 0 & 0 \\
\hline Slovakia & 21.3 & 9.5 & 2.7 & 79.4 & 24 & 1310 \\
\hline
\end{tabular}

Source: Atlas rómskych komunít na Slovensku, 2004

Approximately $90 \%$ of Roma dwellings in segregated settlements are not connected to the public sewage line. Sewage is completely missing in Roma settlements in the administrative region of Nitra and it is indeed minimal in administrative regions of Prešov, Košice or Trnava $(0.9 \%, 9.3 \%$ and $10.8 \%$ of dwellings respectively). Scarce installations and use of sewage was also found in Roma settlements in administrative regions of Košice (dwellings) and Trnava (dwellings).

Out of the individual technical networks, presence of which was traced, the Roma scarcely use that of gas at all. Only a negligible fragment of segregated settlements possesses a gas connection $(2.7 \%$ dwellings). It is due to the bad social situation of many Roma families who cannot afford installation of gas connection in their dwellings. Other important barrier to gas connection is the distance of the Roma settlements from the adjacent municipalities (several kilometres in some cases). 
Four indicators were used in classification of the Roma settlements in terms of their infrastructure: Shares of the Roma dwellings using electricity, water main, gas and sewage. The point or ball method where each of the four indicators was recalculated into points was used. The point scale of 1 to 10 made possible the differentiation of Roma settlements according to the existing infrastructure and its use. Point value of 1 was the lowest level while 10 indicated the best infrastructure and its full use. The total point value was the criterion for the typification of Roma settlements. The range of values moved between 40 (the maximum of 10 points for all indicators) and 4 where every indicator was attributed the least points (tab. 3).

Table 3 Score settlements by use of elektricity, water, sewage and gas mains

\begin{tabular}{|c|c|c|c|c|c|c|c|c|}
\hline values & $\begin{array}{c}\text { proportion } \\
\text { of } \\
\text { dwellings } \\
\text { in the } \\
\text { settlements } \\
\text { connected } \\
\text { to } \\
\text { electricity }\end{array}$ & $\begin{array}{c}\text { number } \\
\text { of } \\
\text { settlements }\end{array}$ & $\begin{array}{c}\text { proportion } \\
\text { of } \\
\text { dwellings } \\
\text { in the } \\
\text { settlements } \\
\text { connected } \\
\text { to water } \\
\text { supply }\end{array}$ & $\begin{array}{c}\text { pettlements } \\
\text { of } \\
\text { sumber }\end{array}$ & $\begin{array}{c}\text { proportion } \\
\text { of } \\
\text { dwellings } \\
\text { in the } \\
\text { settlements } \\
\text { connected } \\
\text { to } \\
\text { sewerage }\end{array}$ & $\begin{array}{c}\text { proportion } \\
\text { of } \\
\text { number } \\
\text { of } \\
\text { settlements } \\
\text { in the } \\
\text { settlements } \\
\text { connected } \\
\text { to gas } \\
\text { mains }\end{array}$ & $\begin{array}{c}\text { number } \\
\text { of } \\
\text { settlements }\end{array}$ \\
\hline $\mathbf{1}$ & 0 & 35 & 0 & 486 & 0 & 1151 & 0 & 768 \\
\hline $\mathbf{2}$ & $1-19$ & 9 & $1-19$ & 71 & $1-19$ & 25 & $1-19$ & 113 \\
\hline 3 & $20-29$ & 9 & $20-39$ & 93 & $20-29$ & 9 & $20-29$ & 67 \\
\hline $\mathbf{4}$ & $30-39$ & 7 & $40-49$ & 35 & $30-39$ & 18 & $30-59$ & 147 \\
\hline $\mathbf{5}$ & $40-49$ & 14 & $50-59$ & 72 & $40-59$ & 23 & $60-69$ & 51 \\
\hline $\mathbf{6}$ & $50-59$ & 28 & $60-69$ & 61 & $60-69$ & 14 & $70-79$ & 29 \\
\hline $\mathbf{7}$ & $60-79$ & 47 & $70-79$ & 45 & $70-79$ & 11 & $80-84$ & 19 \\
\hline $\mathbf{8}$ & $80-89$ & 64 & $80-89$ & 75 & $80-89$ & 20 & $85-89$ & 29 \\
\hline $\mathbf{9}$ & $90-99$ & 81 & $90-99$ & 39 & $90-99$ & 18 & $90-99$ & 19 \\
\hline $\mathbf{1 0}$ & 100 & 1113 & 100 & 430 & 100 & 118 & 100 & 165 \\
\hline
\end{tabular}

Source: Atlas rómskych komunít na Slovensku, 2004

The share of Roma dwellings connected to one of infrastructure networks oscillated between $0 \%$ and $100 \%$. The number of dwellings classified into one of the established categories was different for each network. The final number of Roma settlements included into the classification was 1,407 (in case of 168 settlements, all attempts to set the number of dwellings connected to electricity, gas, water main or sewage failed). 
Pursuing the described point method, five categories of Roma settlements have been classified:

Settlements where each dwelling is connected to electricity, gas, water main and sewage were classified into the $1^{\text {st }}$ category. Only 51 settlements populated by 9,077 Roma persons living in 1,665 dwellings exist in Slovakia and the quality of life is best there (tab. 4).

Table 4 Categories of Roma settlements by summary point value

\begin{tabular}{|c|c|c|c|c|c|}
\hline $\begin{array}{c}\text { category } \\
\text { of Roma } \\
\text { settlements }\end{array}$ & points range & $\begin{array}{c}\text { number } \\
\text { of } \\
\text { settlements }\end{array}$ & $\begin{array}{c}\text { proportion } \\
\text { of Roma } \\
\text { settlements } \\
\mathbf{( \% )}\end{array}$ & Population & $\begin{array}{c}\text { proportion } \\
\text { of the } \\
\text { population } \\
\text { (\%) }\end{array}$ \\
\hline I. & 40 & 51 & 3.62 & 9077 & 4.43 \\
\hline II. & $30-39$ & 166 & 11.80 & 31981 & 15.62 \\
\hline III. & $20-29$ & 450 & 31.98 & 60178 & 29.40 \\
\hline IV. & $10-19$ & 670 & 47.62 & 93536 & 45.69 \\
\hline V. & $0-9$ & 70 & 4.98 & 9926 & 4.85 \\
\hline
\end{tabular}

Source: Atlas rómskych komunít na Slovensku, 2004

The $2^{\text {nd }}$ category covers settlements that reached 30-39 points of the scale. All 166 Roma settlements classified into this category are well served in terms of infrastructure as the overwhelming majority of dwellings possess all relevant engineering networks. In the settlements of the $2^{\text {nd }}$ category a total 31,981 Roma persons live in 4891 dwellings. Quality of life in these settlements is on a comparatively good level.

The $3^{\text {rd }}$ category contains the Roma settlements, which reached 20-29 points. In Slovakia, there are 450 settlements of the $3^{\text {rd }}$ categories with the total Roma population of 60,178 living in 8,935 dwellings. Quality of life of population in settlements classified into the $3^{\text {rd }}$ category is average. The communities use the two basic engineering networks (electricity and water main).

The $4^{\text {th }}$ category is the one containing the Roma settlements that reached 10-19 points. In Slovakia, there are 670 settlements of the $4^{\text {th }}$ category inhabited by 93,536 persons belonging to the Roma people in 14,359 dwellings. The worst equipped are settlements of Bot’any, Poprad, Neporadza, Rakytník, Vrbov, Pravica, Plešivec, Kendice, Vel'ká nad Ipl'om, Galanta, Vyškovce nad Ipl'om, Boliarove, Ivanica, Svinia, Licince, Egreš, Háj, Kapušany, Moldava nad Bodvou, Nitrianske Hrnčiarovce, Prakovce, and Otročok. Presumably, the quality of life of inhabitants living in the settlements of the $4^{\text {th }}$ category is on a low level as far as the use of technical infrastructure is concerned.

The worst served are the dwellings in settlements of the $5^{\text {th }}$ category, which contains settlements attributed 9 and less points of the point scale. In Slovakia, there are 70 Roma settlements of this bottom category where 9,926 Roma live in 1,386 dwellings. 
This category though, can be divided into two where in the first group some dwellings are connected to some network. The second subgroup contains settlements with completely absent infrastructure of any kind. Their inhabitants live without electricity, water mains, sewage or gas supply. There are 29 such settlements in Slovakia. They are settlements next to the municipalities of: Dobrá Niva, Drahňov, Fil'akovo, Galanta, Hažín, Henckovce, Horňa, Horná Seč, Horné Mladonice, Kameňany, Kyjatice, Letanovce, Malé Trakany, Milpoš, Ortut’ová, Ožd’any, Ploské, Prašník, Revúca,

Rohožník, Ruská, Santovka, Sása, the housing estate of Ťahanovce, Spišské Bystré, Stará Kremnička, Svrčinovec, and two settlments next to Cerov. Settlements with absenting infrastructure are populated by 1,379 persons. Quality of life in settlements of the $5^{\text {th }}$ category is on a very low level. These are precisely the settlements requiring attention of projects aimed at the improvement of the living conditions of their prevailingly socially dependent population.

\section{Conclusion}

The Roma people as the ethnic minority do not form a homogeneous entity. Individual Roma communities are highly differentiated. The results of typification of Roma settlements also reveal some distinct differences between individual settlements. Differences are sometimes also found between settlements in the territory of the same municipality. Typification of the Roma settlements by the share of dwellings making use of technical infrastructure (electricity, water, gas mains, and sewage) at least partially points to these differences existing between settlements and simultaneously also pinpoints those Roma settlements where the situation in use of infrastructure is the worse.

A rather simplified interpretation of exclusion is that it is general disadvantaging of individuals or population groups with regard to their employment, dwelling or participation in financial resources and decision-making.

A topical question, particularly that connected with the solution and elimination of these negative phenomena, emerged during the study of mechanisms and forms of social exclusion. The possible answer is social inclusion, it means inclusion of the marginalized individuals and groups into the social mainstream. Social cohesion as a certain form of social reconciliation when differences are levelled up and social exclusion is minimal should be the result. Like exclusion, inclusion is also multidimensional and a strong dependence exists between the individual dimensions. Three of many dimensions are considered important: inclusion into the world of labour, provision of adequate habitation, access to education, working skills and qualifications.

\section{References}

ANTALOVÁ, I. (2002): Chaos totalos - Správy z geta. G plus G, Praha.

DAVIDOVÁ, E. (1995): Romano drom - cesty Romů. Univerzita Palackého. Olomouc.

DŽAMBAZOVIČ, R., JURÁSKOVÁ, M. (2002): Sociálne vylúčenie Rómov na Slovensku. In: Vašečka, M. ed.: Čačipen pal o Roma. Súhrnná správa o Rómoch na Slovensku. Inštitút pre verejné otázky, Bratislava, pp. 527-564. 
DŽAMBAZOVIČ, R. (2004): Možnosti sociálnej inklúzie Rómov cez rozvoj rómskej kultúry. In: Rómska kultúra na Slovensku v 21. storočí. Lilium aurum, Dunajská Streda, pp. 75-80.

HORVÁTHOVÁ, J. (2002): Kapitoly z dějin Romů. Společenství Romů na Moravě a Muzeum romské kultury, Praha.

JAKOUBEK, M., PODUŠKA, O. (2003): Romské osady v kulturologické perspektivě. Nakladatel'stvo Doplněk, Brno.

AMNESTY INTERNATIONAL (2007): Slovensko: Stále segregovaní, stále v nerovnom postavení. [Citované 16. apríl 2009.] Dostupné na internete: $<$ http://www.amnesty.sk/article_files/AI_SK_Sprava _vzdelavanie_na_Slovensku.pdf $>$

SVETOVÁ BANKA, INŠTITÚT PRE OTVORENÚ SPOLOČNOSŤ, INEKO, Nadácia S.P.A.C.E, 2002: Chudoba Rómov a sociálna starostlivost' o nich v Slovenskej republike. Bratislava,

RADIČOVÁ, I. (2002): Rómovia na prahu transformácie. In: Súhrnná správa o Rómoch na Slovensku. Inštitút pre verejné otázky, Bratislava, pp. 79-92.

RADIČOVÁ, I. ed. (2004): Atlas rómskych komunít na Slovensku. Inštitút pre verejné otázky, Bratislava.

SEDOVÁ, T. (2007): K problematike exklúzie z pohl'adu politickej a sociálnej filozofie. In: Čambalíková, M., Sedová, T. eds.: Exklúzia a sociálna situácia na Slovensku. Vysoká školka Sládkovičovo, pp. 13-32.

Summary

Social exclusion is understood as an exclusion of a group or individual from some socio-economic, political or cultural system. It is connected with appurtenance of persons to a social group, level of which is different in terms of education, culture, living standard, etc. As a rule, these are negative deflections compared with the characteristics of the majority, particularly in terms of a lower quality of life of social groups and their margining. The following aspects of social exclusion are often: (1) Possibilities of employment, (2) The course and realization of education, (3) Health care, and (4) The dwelling level. The dwelling level of the Roma population (Gypsies) in Slovakia has been assessed based on information acquired during the sociological mapping carried out in 2003-2004. This survey concentrated on indicators like location of the Roma settlements, transport accessibility, number of inhabitants, number of dwellings in settlements, and the basic technical infrastructure. Primarily, the objective of this paper is to assess the basic infrastructure like the existence of water, electricity, and gas mains and the sewage in Roma settlements. Comparison of infrastructure available to the majority in concerned municipalities and that used by the local Roma community is also important and illustrative for the exclusion of the Roma population. A comparatively lower dwelling level has been observed above all in segregated Roma settlements. These settlements seem to be marginalized and it is precisely where the mentioned exclusion is obvious not only in terms of the dwelling level but also in terms of working opportunities, education and health care. Information about spatial differentiation of the dwelling quality of the Roma ethnicity in Slovakia also represents a considerable contribution to the overall knowledge of the theme.

Jozef Mládek, Jana Pukačová Comenius University in Bratislava, Faculty of Natural Sciences Department of Human Geography and Demogeography Mlynská dolina 84215 Bratislava Slovak Republic e-mail:mladek@fns.uniba.sk,pukacova@fns.uniba.sk 